http://jmscr.igmpublication.org/home/ ISSN (e)-2347-176x ISSN (p) 2455-0450

crossref DOI: https://dx.doi.org/10.18535/jmscr/v7i11.26

Journal Of Medical Science And Clinical Research

\title{
A Study of Knowledge, Attitude and Practice of Contraception in Reproductive Age Group in Amritsar District of Punjab
}

Authors

\author{
Dr Rupinder Kaur ${ }^{1}$, Dr Neeraj Bisht ${ }^{2}$, Dr Amrit Dhillon ${ }^{3}$
}

${ }^{1}$ Senior Resident, Department of Obstetrics and Gynecology, Government Medical College Amritsar

${ }^{2}$ Senior Resident, Department of Pathology, Government Medical College Amritsar

${ }^{3}$ Professor, Department of Obstetrics and Gynecology, Government Medical College Amritsar

*Corresponding Author

\section{Dr Surinder Kumar}

Senior Resident, Department of Orthopedics, Government Medical College Amritsar, India

\begin{abstract}
India was the first country in the world to formulate the national family planning programme in the year 1952 with the objective of "reducing the birth rate to the extent necessary to stabilize the population at a level consistent with requirement of national economy. The objective of this study was to study contraceptive use among married women of reproductive age group in Amritsar district of Punjab. A cross sectional study was conducted from May 2015 to April 2016. In the department of obstetrics and gynecology department of Government medical college and hospital, Amritsar among the married women in eligible couple group attending the hospital.

Sample size was calculated to be 200. Inclusion criteria was married couple with female in age group of 15 45 years, sexually active and who were willing to participate in this study. Maximum number of women i.e. 95\% were between age of 15-34 yrs. Majority were Sikhs 67\%, 32\% were hindu and only $1 \%$ were Christians. 34\% were from urban area and 66\% were from Rural area. Maximum women were housewives i.e. $89.5 \%$. 10.5\% were working. $81 \%$ had heard about family planning. $64 \%$ were aware of contraception. $57 \%$ knew where to get contraceptives from. For $64.1 \%$ women the concept of family planning was having a small family. In 35.8\% women had the concept of Birth spacing. In our study only 64\% of population was aware about contraception. $86.7 \%$ were aware of oral pills, $97.6 \%$ were aware of condoms, $50.7 \%$ were aware of copper T $44.5 \%$ were aware of tubectomy, only $10.9 \%$ were aware of vasectomy.

Conclusion: Though overall acceptance of contraception over a decade has increased, the usage of pills and intra-uterine contraceptive devices has remained same. The rise in acceptance is mainly attributed to sharp rise in usage of male barrier contraception. Collective effort from the government, health care providers and society is needed. Educational and motivational activities from doctors and health workers are needed to promote the use of contraception.
\end{abstract}

Keywords: contraception, reproductive age group, family planning.

\section{Introduction}

India is still among the overpopulated countries of the world. Uncontrolled population growth is the main hurdle to the positive development of the country. India was the first country in the world to formulate the national family planning programme in the year 1952 with the objective of "reducing the birth rate to the extent necessary to stabilize 
the population at a level consistent with requirement of national economy. ${ }^{[1]}$. Though there are many methods of contraception available, many women are still not willing to adopt them due to social factors. A lot of effort has been made by National family welfare programme but still a lot more needs to be done as far as the awareness is concerned.

Family planning is defined by WHO as a way of thinking and living that is adopted voluntarily upon the basis of knowledge, attitude and responsible decisions by individuals and couples in order to promote health and welfare of family groups and thus contribute effectively to contribute effectively to social development of a country. Family planning assists "families in achieving the number of children desired with appropriate spacing and timing, ensuring optimal growth and development of each family member". Failure to plan a pregnancy can adversely affect the health of the mother, the child and the families as a whole. It also protect from high-risk pregnancy, unsafe abortion, reproductive tract infection and STDs including HIV/AIDS. The international conference on population and development (ICPD) defined voluntary family planning services as a fundamental human right as well as couples' right. Gaps in reproductive health/family planning and sexual health care account for nearly $1 / 5$ th of the worldwide burden of illness and premature death and 1/3rd of illness and death among reproductive age group women. ${ }^{\text {[2] }}$

A successful population control program requires much more than mere provision of family planning devices or methods ${ }^{[3,4,5]}$. In recent years the need to study and understand the factors responsible for the acceptance of family planning and the practices by particular communities has been felt. From such studies, more specific knowledge can be gained about the factors that determine the acceptance of family planning. This study was carried out to assess the awareness and usage of birth control and spacing methods among women attending a tertiary hospital.

\section{Methods}

A cross sectional descriptive study was conducted in department of Obstetrics and Gynaecology in Bebe Nanaki Mother and Child Care Centre/ Guru Nanak Dev Hospital Complex in Amritsar district of Punjab. The study group included 200 women of reproductive age group ( 15 - 45 years) from May 2015 to April 2016.

\section{Inclusion Criteria}

Reproductive age group women (15-45 years) visiting Bebe Nanaki Mother and Child Care Centre/ Guru Nanak Dev Hospital Complex, Amritsar who were willing to participate in this study.

\section{Exclusion Criteria}

Women below the age of 15 and above 45 and those who were not willing to participate in our study.

\section{Sampling}

Sampling was done by snowball technique.

A well structured questionnaire was used for data collection. This included basic information, knowledge and attitude regarding family planning methods and contraceptive practices. The data was collected by questionnaire by interview technique.

\section{Results}

Age: Out of 200 women ( $\mathrm{n}=200), 90$ women were in age group $15-24$ years i.e. $45 \%$.

100 women were between $25-34$ years i.e. $50 \%$.

10 women were $35-44$ years old i.e. $5 \%$.

Maximum number of women i.e. $95 \%$ were between age of 15-34 yrs.

\begin{tabular}{|l|c|c|}
\hline AGE GROUP & NUMBER & PERCENTAGE \\
\hline $15-24$ & 90 & $45 \%$ \\
\hline $25-34$ & 100 & $50 \%$ \\
\hline $35-44$ & 10 & $05 \%$ \\
\hline
\end{tabular}

Religion: 134 women out of 200 were Sikhs (Punjab has majority Sikh population), which makes 67\%, 64 women from Hindu religion i.e. $32 \%$ and 2 women were Christians i.e. $1 \%$.

\begin{tabular}{|l|c|c|}
\hline RELIGION & NUMBER & PERCENTAGE \\
\hline SIKH & 134 & $67 \%$ \\
\hline HINDU & 64 & $32 \%$ \\
\hline CHRISTIAN & 02 & $01 \%$ \\
\hline
\end{tabular}


Literacy: $64 \%$ of women were below matriculation of education. $9 \%$ were graduate. $10 \%$ women were senior secondary pass. $17 \%$ were matric pass. $26 \%$ were $8^{\text {th }}$ std. pass and $38 \%$ were $5^{\text {th }}$ std. \& less.

\begin{tabular}{|l|c|c|}
\hline EDUCATION & NUMBER & PERCENTAGE \\
\hline GRADUATE & 18 & $9 \%$ \\
\hline SENIOR SECONDARY & 20 & $10 \%$ \\
\hline 10 th & 34 & $17 \%$ \\
\hline 8 th & 52 & $26 \%$ \\
\hline $5^{\text {th }}$ AND LESS & 76 & $38 \%$ \\
\hline
\end{tabular}

Maximum Number (64\%) of Women were below Matric Level of Education.

Marital Status: All women in study group were married.

Occupation: Maximum women were housewives i.e. $89.5 \%$. 21 women i.e. $10.5 \%$ were working. 179 women i.e. $89.5 \%$ were housewives.

\begin{tabular}{|l|c|c|}
\hline OCCUPATION & NUMBER & PERCENTAGE \\
\hline WORKING & 21 & $10.5 \%$ \\
\hline HOUSEWIFE & 179 & $89.5 \%$ \\
\hline
\end{tabular}

Rural/Urban: 68 women i.e. $34 \%$ were from urban area 132 women i.e. $66 \%$ were from Rural area.

\begin{tabular}{|l|c|c|}
\hline AREA & NUMBER & PERCENTAGE \\
\hline URBAN & 68 & 34 \\
\hline RURAL & 132 & 66 \\
\hline
\end{tabular}

\section{Knowledge \& Awareness}

162 women i.e. $81 \%$ had heard about family planning.

128 women i.e. $64 \%$ were aware of contraception.

114 women i.e. $57 \%$ knew where to get contraceptives from.

\section{Source of Knowledge}

In 58 women i.e. $35.8 \%$ media (T.V., Magazines, Newspapers, Radio) was the source of knowledge. In 29 women i.e. $17.9 \%$ source of knowledge were friends

in $46.2 \%$ i.e. 75 women source of knowledge was health personnel (Doctor, Nurse, ANM, ASHA).

\begin{tabular}{|l|c|c|}
\hline SOURCE & NUMBER & PERCENTAGE \\
\hline MEDIA & 58 & $35.8 \%$ \\
\hline FRIENDS & 29 & $17.9 \%$ \\
\hline HEALTH PERSONNEL & 75 & $46.2 \%$ \\
\hline
\end{tabular}

\section{Concept of Family Planning}

For $64.1 \%$ women the concept of family planning was having a small family. In $35.8 \%$ women had the concept of Birth spaing.

\begin{tabular}{|l|c|c|}
\hline CONCEPT & NUMBER & PERCENTAGE \\
\hline SPACING & 58 & $35.8 \%$ \\
\hline SMALL FAMILY & 104 & $64.1 \%$ \\
\hline
\end{tabular}

\section{Awareness about Contraception}

In our study only $64 \%$ of population was aware about contraception $(n=128)$.

\section{Contraceptive Methods Awareness}

111 Women i.e. $86.7 \%$ were aware of oral pills. 125 women i.e. $97.6 \%$ were aware of condoms. 65 women i.e. $50.7 \%$ were aware of copper $t$.

51 women i.e. $44.5 \%$ were aware of tubectomy. 14 women i.e. $10.9 \%$ were aware of vasectomy. 15 women i.e. $11.7 \%$ were aware of Injectables.

\begin{tabular}{|l|c|c|}
\hline CONRACEPTIVES & NUMBER & PERCENTAGE \\
\hline ORAL PILLS & 111 & $86.7 \%$ \\
\hline CONDOMS & 125 & $97.6 \%$ \\
\hline CuT & 65 & $50.7 \%$ \\
\hline TUBECTOMY & 57 & $44.5 \%$ \\
\hline VASECTOMY & 14 & $10.9 \%$ \\
\hline INJECTABLES & 15 & $11.7 \%$ \\
\hline
\end{tabular}

\section{Sources of Availability}

Out of 114 women who knew where to get contraceptives from, 86 women were aware that contraceptives are easily available at government health centres and is provided by local health personnel like ANM.

Only $24.5 \%$ women were aware regarding the availability of contraceptives from medical shops.

Attitude: Out of 162 women who had heard of family planning 148 i.e. believed that contraceptives were beneficial.

98 women i.e. $60.4 \%$ were willing to advice their friends and relatives regarding family planning practices.

140 women i.e. $86.4 \%$ were willing for family planning in future after our counselling.

\section{Practice}

120 women had used contraceptives at some point in their life. Among the users $88.3 \%$ had used condoms, while only $46.6 \%$ had used oral pills 
only $10 \%$ of women had used CuT in the past, $5 \%$ of women had undergone tubectomy.

\section{Observations}

During the interview it was observed that for most of the women condom was the preferred method. In $56.6 \%$ cases the choice of contraception was done by the husband.

There is seen a preference of male child since most of the women wished to undergo tubectomy only after they had a male child.

\section{Discussion}

The United Nations has estimated that the world population grew at an annual rate of 1.23 percent during 2000 - 2010. With a definite slowing down of population growth in china, it is now estimated that by 2030 , India will most likely overtake china to become the most populous country on the earth with 17.9 percent population living here. ${ }^{[6,7]}$

This will definitely put an enormous pressure on the natural resources of the country and also cause unlimited urbanization, unemployment, overcrowding, ill health, environmental pollution etc. The solution of this rapidly increasing population is Family planning in order to achieve economical and social develop-ment ${ }^{[8]}$. voluntary ac-ceptance of one of the approved contraceptive methods is required which can be achieved through health education and motivation. Today even though increased facilities are being provided for family planning program in all sections of the society, there are other factors that play an important role in adopting it like knowledge, attitude, beliefs, values, misconceptions etc.

Awareness prevails without acceptance Illitera-cy, poverty and social norms are the root causes. ${ }^{[9]}$ Lack of effective health care system Misbe-lieves, half or wrong information received from friends and relatives and consequent develop-ment of fear about contraceptives are main causes for low level of acceptance and usage of contraception in our community ${ }^{[10]}$. Also knowledge and acceptance does not go hand in hand ${ }^{[11]}$. As acceptance and usage is related to literacy and socio-economic status, it is necessary to motivate couples for usage as well as make sure about availability of services $^{[12]}$. Education of masses, upliftment of economic standards, strong political support are needed to increase the usage of contraception ${ }^{[13]}$. The present study aimed to assess awareness and usage of birth control and birth spacing methods among women attending tertiary hospital which caters to both urban and rural women. In our study maximum subjects i.e. $95 \%$ were between age group of 15-34 years which is comparable to the study by renjhen prachi et al in east Sikkim ${ }^{[14]}$.

The age group characteristics were similar to the study conducted by Shrivastava et al in Ghorakhpur ${ }^{[15]}$ but in their study nearly half of the women were illiterate and from rural background. In our study most of the women were illiterate and from rural background which is comparable to study by Shrivastava et al in Gorakhpur ${ }^{[15]}$. Mohanan et $\mathrm{al}^{[16]}$ in a study from Dakshina Kannada concluded that majority $(52.4 \%)$ of the women using contraception were in the age group of 15-34 years. In our study only $64 \%$ of population was aware about contraception which is lower as compared to the Nair RV et al.

In most of the previous studies maximum women were Hindu but in our study $67 \%$ women were Sikhs who are a majority in Punjab.

In our study maximum women had gained information from health personal while in study by renjhen et al maximum subjects had gained information from media. In Srivastava et $\mathrm{al}^{[15]}$ study $70 \%$ had gained knowledge of contraceptives from friends and family and 39\% from television and radio. A study by Kara $\mathrm{K}$ et al show that the most common sources of information were mass media, friends, and healthcare workers. ${ }^{[17]}$

Similar findings were reported in studies in Kilimanjaro $^{[18]}$ and Botswana. ${ }^{[19]}$

In our study $97.6 \%$ women knew about condoms and $86.7 \%$ about oral pills, $50.7 \%$ about $\mathrm{CuT}$ and $44.5 \%$ about tubectomy while in Srivastva et al ${ }^{[15]}$ study $82 \%$ were aware about female sterilization, $50 \%$ were aware of vasectomy, and IUCD was the 
most known (61\%) temporary method followed by OC pills (60\%) and condoms (50\%). Knowledge and awareness about vasectomy and injectables was very less in our study i.e. $10.9 \%$ and $11.7 \%$ respectively where as in study by renjhen et $\mathrm{al}^{[14]}$ maximum awareness was of OCP's.

Our study highlights that knowledge and awareness doesn't always lead to the use of contraceptives. Collective effort from the government, health care providers and society is needed. Educational and motivational activities from doctors and health workers are needed to promote the use of contraception. The correct use of contraception can prevent unintended pregnancies, unsafe abortions, and sexually transmitted infections, including HIV. ${ }^{[20]}$

\section{Conclusion}

One needs to understand the level of awareness and practices in the community before implementing the family planning program. There is a need to educate and motivate the couples along with improvement in family planning services to promote the contraceptives.

\section{References}

1. Kansal A, Chandra R, Kandapal SD, Negi KS. Epidemiological correlates of contraceptive prevalence in rural population of Dehradun District. Indian Journal of Community Medicine. 2005;30(2):60.

2. Arbab AA, Bener A, Abdulmalik M. Prevalence, awareness and determinants of contraceptive use in Qatari women. EMHJ. 2011;17(1):11-8.

3. WHO (1999), Health situation in SE Asia Region 1994-1997, Regional office for SEAR, New Delhi.

4. WHO (2001) World Health Report: New Understanding, New Hope.

5. Dept of Family Welfare (1992), Ministry of Health and Family Welfare, Govt of India.
6. Nair RV, Ashok VG, Solanke PV. A study on contraceptive use among married women of reproductive age group in a rural area of Tamilnadu, India. Int $\mathbf{J}$ Reprod Contracept Obstet Gynecol. 2016 Sept;5(9):3147-3152.

7. Size, growth, rate and distribution of population, 2011. Available at http://censusindia.gov.in/2011provresults/ data_files/india/Final_PPT_2011_chapter3 .pdf. Accessed on 24 January 2015.

8. Dhar GM, Shah GN, Bhat IA, Butt N. Low Birth Weight: an outcome of poor socio obstetric interaction. Indian Journal of Maternal and Child Health 1991; 2(1) : 103.

9. Ranjheh P, Gupta S, Barua A, Jaju S, Khati B. A study of knowledge of, attitude and practice of family planning among the women of reproductive age group in Sikkim. J Obst Gynecol India 2008;58 : 63-67.

10. Cornelius RM. Towards an understanding of the KAP gap. Presented at the annual meeting of the population Association of America, San Francisco. 1986; 3990P.

11. Malhotra S, Dua D, Suman K. Unmet need for planned family in the women of union territory of Chandigarh. J Obst Gyn India 2002; $52: 150-52$.

12. Dalal AR, Thanawala UJ, Rawal MY. Knowledge, use and attitudes towards family planning. J Obst Gynecol India 1989; 39: 424-26.

13. Shah AN. Changing trends in the acceptance of contraceptive methods :j obst gynaecol of India:2007:57:533-539

14. Renjhen P , Gupta SD , Barua A , Jaju S , Khati B , Sikkim . A KAP Study of family planning among women of reproductive age group in Sikkim.

15. Srivastava R, Srivastava D K, Jina R et al. Contraceptive knowledge attitude and practice (KAP)survey J Obstet Gynecol India 2005;55:546-50.2. 
16. Donati S, Sharma N, Medda $M$ et al. Family planning knowledge attitude and practice survey in Manipur estate $\mathrm{J}$ Obstet Gynecol India 2003;53:485- 90.

17. Kara K, Bendicto M, Mao J. Knowledge, Attitude, and Practice of Contraception Methods Among Female Undergraduates in Dodoma, Tanzania. Cureus 2019 Apr 11(4) doi: 10.7759/cureus.4362.

18. Sweya MN, Msuya SE, Mahande MJ, Manongi R. Contraceptive knowledge, sexual behavior, and factors associated with contraceptive use among female undergraduate university students in Kilimanjaro region in Tanzania. Adolesc Health Med Ther [Aug; 2018]; 2016 3:109-115.

19. Hoque ME, Ntsipe T, Mokgatle-Nthabu M. Awareness and practices of contraceptive use among university students in Botswana. [Dec;2018]; Sahara J. $2013 ; 10: 83-88$.

20. Ong J, Temple-Smith M, Wong WCW, McNamee K, Fairley C Contraception matters: indicators of poor usage of contraception in sexually active women attending family planning clinics in Victoria, Australia. [Oct;2018]; BMC Public Health. $2012 ; 3: 1108$. 